\title{
PENGARUH TEKNIK RELAKSASI BENSON TERHADAP GULA DARAH PASIEN DM TIPE II
}

\author{
Ade Rahman \\ Akademi Keperawatan Kesdam I/BB Padang \\ Email : rahmanade370@gmail.com
}

\begin{abstract}
ABSTRAK
Diabetes mellitus adalah gula darah yang melebihi batas normal atau gula darah yang meningkat dalam jangka waktu lama akan menyebabkan kelainan system saraf yang disebut neuropati diabetic dan kelainan pembuluh darah (Helmanu, 2015) yang dapat diobati secara farmakologis (insulin) dan non farmakologis (terapi, contoh ; relaksasi benson). Penelitian ini bertujuan untuk mengidentifikasi pengaruh relaksasi benson terhadap gula darah pasien DM Tipe II. Desain penelitian quasi experiment One Group Pretest-Posttest terhadap 10 orang lansia dengan DM Tipe II yang memenuhi kriteri inklusi. Gula darah diukur menggunakan Glucocheck. Uji statistik yang digunakan adalah uji t berpasangan. Gula darah rata-rata pretest pada lansia adalah 279,5 gr/dL. Setelah diberikan relaksasi Benson selama 3 hari berturut-turut didapatkan gula darah rata-rata post test nya adalah $239,8 \mathrm{gr} / \mathrm{dL}$ dan didapatkan $(\mathrm{p}=0,000)$. Dengan demikian relaksasi benson efektif untuk menurunkan gula darah pada lansia dengan DM Tipe II. Jadi disarankan kepada responden, RS, perawat dan peneliti selanjutnya bahwa kita dapat menggunakan terapi relaksasi benson sebagai cara alternative atau pengobatan nonfarmakologi pada penderita DM Tipe II.
\end{abstract}

\section{Kata Kunci : Relaksasi Benson, Lansia, DM Tipe II}

\begin{abstract}
Diabetes mellitus is blood sugar that exceeds normal limits or blood sugar that rises for a long time will cause a nervous system disorder called diabetic neuropathy and blood vessel abnormalities (Helmanu, 2015) that can be treated pharmacologically (insulin) and non pharmacologically (therapy, for example, benson relaxation). This study aims to identify the effect of Benson's relaxation on blood sugar in Type II DM patients. The research design is a quasi-experimental One Group Pretest-Posttest of 10 elderly people with Type II diabetes who meet the inclusion criteria. Blood sugar is measured using Glucocheck. The statistical test used was a paired $t$ test. The average pretest blood sugar in the elderly is $279.5 \mathrm{gr} / \mathrm{dL}$. After Benson's relaxation for 3 consecutive days, his average post-test blood sugar was $239.8 \mathrm{gr} / \mathrm{dL}$ and was obtained $(p=0,000)$. Thus Benson's relaxation is effective for lowering blood sugar in the elderly with Type II DM. So it is suggested to respondents, hospitals, nurses and further researchers that we can use Benson relaxation therapy as an alternative way or nonpharmacological treatment in patients with Type II DM.
\end{abstract}

Keywords : Benson Relaxation, elderly, DM Type II 


\section{PENDAHULUAN}

Diabetes Mellitus (DM) atau kencing manis telah menjadi masalah kesehatan di dunia dengan prevalensi dan insidens penyakit ini meningkat secara drastis di negara-negara maju dan negara-negara industri. Diabetes mellitus adalah gula darah yang melebihi batas normal atau gula darah yang meningkat dalam jangka waktu lama akan menyebabkan kelainan system saraf yang disebut neuropati diabetic dan kelainan pembuluh darah (Helmanu, 2015).

Glukosa darah merupakan gula yang terdapat di dalam darah yang berasal dari karbohidrat dalam makanan dan disimpan sebagai glikogen dihati dan diotot rangka. Glukosa darah berfungsi sebagai penyedia energy bagi tubuh dan jaringan- jaringan yang ada dalam tubuh (Widyatusti, 2015).

Tindakan yang dapat dilakukan untuk mengendalikan kadar glukosa darah pada pasien diabetes melitus yaitu diperlukan penatalaksanaan diabetes melitus meliputi penatalaksanaan farmakologis dan non farmakologis, penatalaksanaan farmakologis dengan pemberian obat dan insulin. Sedangkan non farmakologis yaitu dengan peningkatan koping, memberikan informasi sensori dan prosedural, dukungan sosial, dan latihan relaksasi (Smeltzer \& Bare, 2002).

Relaksasi Benson yaitu relaksasi pernafasan yang melibatkan keyakinan pasien yang dapat membantu pasien mencapai kondisi kesehatan dan kesejahteraan lebih tinggi (Benson \& Proctor, 2012). Keyakinan berpengaruh terhadap fisik maupun jiwa manusia, yaitu relevan dan berpengaruh dalam terapi dan pencegahan penyakit. Keyakinan dapat mempengaruhi dan menyembuhkan hingga 90\% keluhan medis (Benson \& Stark, 2012).

Meditasi yang terdapat pada relaksasi Benson berupa pengulang-ulangan kata/frase, sikap pasif merupakan hal yang essential. Mekanisme penurunan kadar gula darah dengan relaksasi Benson terjadi melalui penurunan stres fisik dan psikologis yang kemudian akan menurunkan epinefrin, menurunkan kortisol, menurunkan glukagon dan menurunkan hormon tiroid. Proses terapi relaksasi Benson bermanfaat dalam menurunkan gula darah, dalam keadaan relaks hormon-hormon akan bekerja normal dan optimal sehingga endorphin dapat diproduksi dengan baik, endorphin 
ini berfungsi untuk mengurangi nyeri dan memperbaiki mood yang secara otomatis sakit yang dirasakan pasien akan mengalami penurunan, ditambah dengan relaksasi pernafasan dalam dan relaksasi progresif otot. Pada kondisi inilah kadar glukosa darah pasien akan normal.

Tujuan umum pada penelitian ini adalah untuk mengidentifikasi pengaruh Relaksasi Benson terhadap kadar gula darah pasien DM Tipe II di Ruang Interne RST Tingkat III Dr. Reksodiwiryo Padang tahun 2020.

\section{METODE}

Jenis penelitian ini merupakan penelitian kuantitatif dengan desain Experimental menggunakan pendekatan Quasi Experimental tanpa kelompok control dengan pendekatan one group pretest posttes (Nursalam, 2008),. Sampelnya adalah lansia dengan DM Tipe II yang berjumlah 10 orang yang didapat dengan metode Purposive sampling dengan kriteria Bersedia menjadi responden saat dilakukan penelitian, Masih kooperatif ,Usia di atas 35 tahun, Mendapatkan obat oral seperti; Metformin, Glimepirid, Gliquidon, Acarbose.

\section{HASIL}

\section{Karakteristik Responden}

Responden dalam penelitian ini berjumlah sepuluh (10) orang lansia dengan DM Tipe II.

1. Karakteristik Responden

a. Jenis Kelamin

Tabel 1.

Distribusi frekuensi responden berdasarkan jenis kelamin pada Pasien DM Tipe II di Ruang Interne RST Reksodiwiryo Padang

\begin{tabular}{|c|c|c|c|}
\hline $\begin{array}{c}\text { N } \\
\text { o }\end{array}$ & $\begin{array}{c}\text { Jenis } \\
\text { kelamin }\end{array}$ & $\begin{array}{c}\text { Frekuensi } \\
(\mathbf{n})\end{array}$ & $\begin{array}{c}\text { Presentase } \\
(\mathbf{\%})\end{array}$ \\
\hline 1 & Laki-laki & 3 & 30 \\
\hline 2 & Perempuan & 7 & 70 \\
\hline 3 & Jumlah & 10 & 100 \\
\hline
\end{tabular}

Dari tabel 1, diketahui bahwa dari 10 orang responden dengan DM Tipe II paling banyak adalah perempuan yaitu sebanyak 7 orang.

b. Usia

Tabel 2.

Distribusi frekuensi responden berdasarkan usia pada Responden dengan DM Tipe II Di Ruang Interne RST Reksodiwryo Padang

\begin{tabular}{|c|c|c|c|}
\hline No & $\begin{array}{c}\text { Usia } \\
\text { (tahun) }\end{array}$ & $\begin{array}{c}\text { Frekuensi } \\
(\mathbf{n})\end{array}$ & $\begin{array}{c}\text { Presentase } \\
(\boldsymbol{\%})\end{array}$ \\
\hline 1 & $40-50$ & 4 & 40 \\
\hline 2 & $51-60$ & 6 & 60 \\
\hline 3 & jumlah & 10 & 100 \\
\hline
\end{tabular}

Dari tabel 2, diketahui bahwa responden dengan DM Tipe II paling banyak adalah penderita dengan usia 51-60 tahun yaitu sebanyak 6 orang. 
c. Lama Menderita DM

Tabel 3.

Distribusi frekuensi responden berdasarkan lama menderita DM pada Responden dengan DM Tipe II Di Ruang Interne RST Reksodiwryo Padang

\begin{tabular}{|c|c|c|c|}
\hline No & $\begin{array}{c}\text { Lama } \\
\text { menderita } \\
\text { DM } \\
\text { (tahun) }\end{array}$ & $\begin{array}{c}\text { Frekuensi } \\
\text { (n) }\end{array}$ & $\begin{array}{c}\text { Presentase } \\
(\%)\end{array}$ \\
\hline 1 & $<5$ tahun & 4 & 40 \\
\hline 2 & $>5$ tahun & 6 & 60 \\
\hline 3 & jumlah & 10 & 100 \\
\hline
\end{tabular}

Dari tabel 3, diketahui bahwa lama responden menderita DM dengan paling banyak adalah $>5$ tahun yaitu sebanyak 6 orang.

d. Frekuensi melakukan aktifitas fisik dalam satu minggu

Table 4.

Distribusi frekuensi berdasarkan frekuensi melakukan aktifitas fisik dalam satu minggu pada Responden dengan DM Tipe II Di Ruang Interne RST Reksodiwryo Padang

\begin{tabular}{|c|c|c|c|}
\hline $\begin{array}{c}\text { N } \\
\mathbf{0}\end{array}$ & $\begin{array}{c}\text { Frekuensi } \\
\text { melakukakan } \\
\text { aktifitas fisik }\end{array}$ & $\begin{array}{c}\text { Frekuensi } \\
(\mathbf{n})\end{array}$ & $\begin{array}{c}\text { Presentase } \\
(\boldsymbol{\%})\end{array}$ \\
\hline 1 & $\begin{array}{c}\text { Tidak } \\
\text { Pernah }\end{array}$ & 8 & 80 \\
\hline 2 & 1 kali & 2 & 20 \\
\hline 3 & jumlah & 10 & 100 \\
\hline
\end{tabular}

Dari table 4 diketahui bahwa responden yang menderita DM Tipe paling banya tidak pernah melakukan aktifitas fisik yaitu 8 orang.

\section{Analisa Univariat}

a. Gambaran Gula Darah sebelum dan sesudah intervensi hari I

Tabel 5.

Distribusi rata-rata skala nyeri responden dengan DM Tipe II sebelum dan sesudah melakukan relaksasi benson di hari 1 RST dr. Reksodiwryo Padang

\begin{tabular}{|c|c|c|}
\hline Responden & $\begin{array}{c}\text { Pre-test } \\
(\mathbf{m g} / \mathbf{d L})\end{array}$ & $\begin{array}{c}\text { Post-test } \\
(\mathbf{m g} / \mathbf{d L})\end{array}$ \\
\hline 1 & 372 & 310 \\
\hline 2 & 402 & 347 \\
\hline 3 & 271 & 230 \\
\hline 4 & 305 & 252 \\
\hline 5 & 242 & 223 \\
\hline 6 & 312 & 289 \\
\hline 7 & 261 & 228 \\
\hline 8 & 297 & 243 \\
\hline 9 & 490 & 412 \\
\hline 10 & 245 & 221 \\
\hline Total : 10 & & Mean : \\
Mean : 319.7 & & 275.5 \\
\hline
\end{tabular}

Dari tabel 5, diketahui bahwa rata-rata gula darah responden di hari I pretest yaitu $319.7 \mathrm{mg} / \mathrm{dL}$ dan gula darah post test adalah $275.5 \mathrm{mg} / \mathrm{dL}$.

b. Gambaran Gula Darah sebelum dan sesudah intervensi hari II

Tabel 6.

Distribusi rata-rata gula darah responden dengan DM Tipe II sebelum dan sesudah melakukan relaksasi benson di hari II RST dr. Reksodiwryo Padang

\begin{tabular}{|c|c|c|}
\hline Responden & $\begin{array}{c}\text { Pre-test } \\
\text { (mg/dL) }\end{array}$ & $\begin{array}{c}\text { Post-test } \\
\text { (mg/dL) }\end{array}$ \\
\hline 1 & 312 & 269 \\
\hline 2 & 345 & 308 \\
\hline 3 & 223 & 206 \\
\hline 4 & 250 & 217 \\
\hline 5 & 223 & 202 \\
\hline 6 & 288 & 239 \\
\hline 7 & 229 & 204 \\
\hline
\end{tabular}




\begin{tabular}{|c|c|c|}
\hline 8 & 245 & 221 \\
\hline 9 & 410 & 372 \\
\hline 10 & 220 & 207 \\
\hline Total $: 10$ & & Mean : \\
Mean $: 274.5$ & & 244.5 \\
\hline
\end{tabular}

Dari tabel 6, diketahui bahwa rata-rata gula darah responden dihari ke II pretest yaitu $274.5 \mathrm{mg} / \mathrm{dL}$ dan gula darah post test adalah $244.5 \mathrm{mg} / \mathrm{dL}$.

c. Gambaran Gula Darah sebelum dan sesudah intervensi hari III

Tabel 7

Distribusi rata-rata skala nyeri responden dengan DM Tipe II sebelum dan sesudah melakukan relaksasi benson di hari III RST dr. Reksodiwryo Padang

\begin{tabular}{|c|c|c|}
\hline Responden & $\begin{array}{c}\text { Pre-test } \\
\text { (mg/dL) }\end{array}$ & $\begin{array}{c}\text { Post-test } \\
\text { (mg/dL) }\end{array}$ \\
\hline 1 & 265 & 209 \\
\hline 2 & 309 & 241 \\
\hline 3 & 205 & 179 \\
\hline 4 & 220 & 182 \\
\hline 5 & 205 & 169 \\
\hline 6 & 235 & 201 \\
\hline 7 & 203 & 164 \\
\hline 8 & 218 & 173 \\
\hline 9 & 375 & 309 \\
\hline 10 & 208 & 172 \\
\hline Total : 10 & & Mean : \\
Mean : 244.3 & & 199.9 \\
\hline
\end{tabular}

Dari tabel 7, diketahui bahwa rata-rata gula darah responden dihari ke III pretest yaitu $244.3 \mathrm{mg} / \mathrm{dL}$ dan gula darah post test adalah $199.9 \mathrm{mg} / \mathrm{dL}$. d. Distribusi frekuensi rata-rata penurunan skala nyeri sebelum dan sesudah intervensi

Tabel 8

Distribusi frekuensi rata-rata penurunan gula darah pasien DM Tipe II sebelum dan sesudah intervensi di Ruang Interne RST Reksodiwryo Padang

\begin{tabular}{|c|c|c|c|}
\hline \multirow{2}{*}{ Distribusi } & \multirow{2}{*}{$\begin{array}{c}\text { Hari } \\
\text { ke }\end{array}$} & \multicolumn{2}{c|}{$\begin{array}{c}\text { Besar } \\
\text { penurunan } \\
\text { gula darah } \\
\text { gr/dL }\end{array}$} \\
\cline { 3 - 4 } & & Pre & Post \\
\hline Gula Darah & 1 & 319.7 & 275.5 \\
& 2 & 274.5 & 244.5 \\
& 3 & 244.3 & 199.9 \\
\hline \multicolumn{2}{|c|}{ Mean } & 279.5 & 239.8 \\
\hline
\end{tabular}

Dari tabel 8 , diketahui rata-rata penurunan gula darah pretest adalah $279.5 \mathrm{mg} / \mathrm{dL}$, dan post op $239.8 \mathrm{mg} / \mathrm{Dl}$

\section{Analisa Bivariat}

Tabel 9

Distribusi penurunan skala nyeri pada responden dengan DM Tipe II sebelum dan sesudah melakukan relaksasi benson di RST Reksodiwryo Padang

\begin{tabular}{|l|c|c|c|c|}
\hline No & $\begin{array}{c}\text { Mean } \\
\text { gula } \\
\text { darah } \\
\text { pre- } \\
\text { test }\end{array}$ & $\begin{array}{c}\text { Mean } \\
\text { gula } \\
\text { darah } \\
\text { post- } \\
\text { test }\end{array}$ & $\begin{array}{c}\text { Mean } \\
\text { penurunan } \\
\text { gula darah }\end{array}$ & $\mathbf{p}$ \\
\hline 1. & 279.5 & 239.8 & 259.5 & 0,000 \\
\hline
\end{tabular}

Berdasarkan tabel 9, diketahui bahwa setelah dilakukan uji statistik dengan uji t berpasangan dengan tingkat kemaknaan $\mathrm{p} \leq 0,05$, diperoleh nilai $\mathrm{p}$ untuk gula darah adalah 0,000 yang artinya secara statistik terdapat penurunan gula darah 
yang bermakna. Hal ini ada pengaruh melakukan relaksasi benson terhadap penurunan gula darah pasien DM Tipe II.

\section{PEMBAHASAN}

\section{a. Karakteristik Responden}

Gula darah responden pasien DM Tipe II di Ruang Interne RST Reksodiwiryo Padang sebelum diberikan teknik relasasi benson adalah $279.5 \mathrm{mg} / \mathrm{dL}$. Dalam penelitian ini, berdasarkan usia , terlihat bahwa responden yang menderita DM Tipe II berusia paling banyak yaitu 51-60 tahun. Intoleransi terhadap glukosa meningkat seiring dengan bertambahnya usi, hal ini disebabkan oleh penurunan senstivitas reseptor insulin, penurunan regulasi hormone glucagon dan epineprin yang mempengaruhi kadar glukosa darah (Black \& Hawks, 2005).

Wanita cenderung mengalami obesitas karena peningkatan hormone estrogen yang menyebabkan peningkatan lemak pada jaringan sub cutis, sehingga wanita mempunyai resiko yang lebih besar terkena diabetes jika mempunyai gaya hidup yang tidak sehat (Corwin, 2009). Hal ini sesuai dengan hasil penelitian penulis, yaitu jika dilihat dari jenis kelamin, pada penelitian ini lebih banyak diderita oleh wanita daripada pria, dimana dari 10 responden 7 diantaranya adalah wanita.

Kurangnya aktifitas fisik juga merupakan salah satu faktor penyebab terjadinya DM (Kurniadi , 2015). Hal ini sesuai dengan hasil penelitian ini, dimana dari 10 responden, 8 orang diantaranya tidak pernah melakukan aktifitas fisik.

Hasil penelitian menunjukkaan bahwa responden memiliki rata-rata lama menderita penyakit DM > 5 tahun. Lama menderita penyakit responden paling lama yaitu 8 tahun. Responden dengan lama waktu menderita DM terendah yaitu 1 tahun. Hasil penelitian ini sesuai dengan hasil penelitian Mutmainah (2013) yang menunjukkan mayoritas responden memiliki lama menderita diabetes antara 1-5 tahun. Waktu lamanya seseorang menderita penyakit dapat memberikan gambaran mengenai tingkat patogenesitas penyakit tersebut (Pratiwi, 2007). Semakin lama seseorang menderita diabetes melitus maka komplikasi penyakit diabetes melitus juga akan lebih mudah terjadi (Pratiwi, 2007). 


\section{b. Perbedaan kadar gula darah sebelum dan sesudah dilakukan relaksasi benson}

Hasil penelitian menunjukkan bahwa relaksasi Benson dapat menurunkan kadar glukosa darah secara signifikan. Hasil penurunan ini karena responden melakukan teknik relaksasi ini dengan benar dan sesuai petunjuk. Selain itu, responden juga tetap rutin mengkonsumsi obat antihiperglikemia sesuai anjuran dokter.

Pada responden yang sudah dilakukan relaksasi benson menunujukkan adanya perbedaan yang bermakna dari gula darah pasien sebelum dan sesudah dilakukan relaksasi benson. Perbedaan ini tampak pada nilai mean yang berbeda antara gula darah sebelum dan sesudah dilakukan relaksasi benson.

Hasil yang bermakna ini sesuai dengan penelitian Kuswandi, dkk. (2008) yang menunjukkan bahwa relaksasi Benson berpengaruh terhadap penurunan kadar glukosa darah pada pasien DM tipe 2. Relaksasi Benson dalam penelitiannya dilakukan dua kali sehari selama 7 hari, pada saat perut kosong. Relaksasi Benson dapat menurunkan kadar gula darah pasien diabetes dengan menekan pengeluaran hormonhormon yang dapat meningkatkan kadar gula darah (Smeltzer, et.all., 2008), yaitu epinefrin, kortisol, glucagon, adrenocorticotropic hormone (ACTH), kortikosteroid, dan tiroid (Smeltzer \& Bare, 2002a; Smeltzer, dkk., 2008, Greinstein \& Wood, 2010).

Temuan penelitian ini juga sejalan dengan temuan Jablon et al (2017) bahwa latihan relaksasi benson yang dilakukan pada pasien DM memberikan hasil terjadinya penurunan gula darah. Jablon et al menyatakan bahwa perbedaan gula darah yang bermakna ini bisa terjadi karena relaksasi benson mempengaruhi hipotalamus untuk memprodukksi kortikosteroid sehingga menurunkan glukogenesis.

Relaksasi Benson menyebabkan tubuh menjadi relaks (Kuswandi, 2008), karena dalam teknik ini terdapat teknik nafas dalam (Smeltzer \& Bare, 2002b). Pada saat menghembuskan nafas sembari mengucapkan katakatafokus yang dipilh (Smeltzer \& Bare, 2002a). Dalam penelitian ini, peneliti memasukkan kata-kata istighfar "Astahfirullah hal'adzim" 
sebagai kata yang dipilih pada saat menghembuskan nafas. Astaghfirulloh hal'adzim merupakan salah satu pendekatan spiritual. Pendekatan spiritual dengan menggunakan psikoreligius dapat mengurangi stres (Miller, et.all., 2011).

Relaksasi Benson akan merangsang sistem limbik (Benson \& Proctor, 2010), sehingga timbul ketenangan (Makhdlori, 2007). Relaksasi Benson menurunkan pengeluaran kortisol (Smeltzer \& Bare, 2002a; Smeltzer, dkk., 2008), yang dapat menurunkan stres (Bilous \& Donelly, 2014).

Relaksasi Benson secara spesifik berperan meningkatkan alirah darah ke otot, jantung dan paru-paru (Jacob, 2011). Akhirnya respon rileks tersebut dapat memicu respon hipotalamaus, yang disebut dengan respon ergotropik, Hess (1957, dalam Jacobs, 2011) menyebutnya sebagai respon relaksasi. Karena stress berhubungan dengan terjadinya penyakit, maka peneliti berasumsi relaksasi benson ini dapat mencegah komplikasi hiperglimeia pada DM. Hal ini sejalan dengan hasil penelitian Kiecolt dan Glaser (1988, dalam Jacobs, 2011) bahwa ada hubungan antara pikiran dan emosi dengan system imun tubuh.
Pernyataan-pernyataan di atas dan dari hasil penelitian ini jelas bahwa relaksasi benson memunculkan kondisi relaks. Pada kondisi relaks terjadi perubahan impuls syaraf pada jalur aferen ke otak dimana aktivasi menjadi inhibisi. Perubahan impuls syaraf ini menyebabkan perasaan tenang baik secara fisik maupun mental seperti berkurangnya denyut jantung, menurunnya kecepatan metabolism tubuh dalam hal ini mencegah peningkatan glukosa darah (Smeltzer dan Bare , 2002). Hipofisis anterior juga diinhibisi sehingga ACTH yang mensekresi kortisol menurun sehingga proses glukogenesis, katabolisme protein dan lemak yang berperan dalam peningkatan glukosa darah menurun (Sudoyo, et al, 2007). Jacobs 2011 menyatakan jika pada organ pancreas ada kerusakan pasokan aliran darah, maka produksi hormone pancreas akan menurun berakibat pada ketidakstabilan gula darah. Dengan relaksasi benson, maka cara untuk mengatasi hal tersebut diharapkan bisa terjadi sehingga pancreas bisa berfungsi dengan baik dan mampu menghasilkan insulin secara normal sehingga kadar gula darah stabil dalam tubuh. 
Adanya perbedaan Gula darah sebelum dan sesudah dilakukan relaksasi benson sesuai dengan asumsi penelitit. Dimana jika dilakukan relaksasi benson maka diharapkan perbedaan gula darah ke angka normal karena terjadi perbaikan pengaturan gula darah melalui perbaikan sirkulasi sehingga hormonehormon termasuk insulin dapat terdistribusi dengan baik ke seluruh tubuh, tetapi jika tidak melakukan relaksasi benson makan gula darah bisa turun, tetap atau bahkan naik dari angka semula cenderung untuk tidak stabil. Hasil temuan adanya pengaruh relaksasi benson terhadap gula darah ini mendukung pernyataan Ernst, et al (2012) bahwa relaksasi benson dapat diterapkan di klinik untuk meningkatkan keterlibatan atau partisipasi klien dalam proses kesembuhan mereka.

Menurut Crisp dan Taylor (2016), individu memiliki sifat yang multidimensi, dimana responnya dalam mengatasi masalah berbedabeda. Tampak pada penelitian ini, dengan perlakuan yang sama dalam terapi relaksasi benson ternyata rentang penurunan gula dara berbedabeda pula. Responden pada penelitian ini melaporkan bahwa mereka merasakan hangat disekujur tubuhnya setelah relaksasi benson. Adapula yang merasakan sakit pada area ulkus berkurang, merasakan lebih relaks. Tetapi ada pula responden yang tidak merasakan sensasi apa-apa. Hal ini sesuai dengan pernyataan Saunders (2015), sensasi yang umumnya dirasakan adalah perasaan panas, hangat, berdenyut, terasa berat atau sama sekali tidak merasakan sensasi. Menurut Davis, et al (2015) semua keadaan tersebut hanyalah peralihan.

Kesimpulan akhir dinyatakan adanya perbedaan gula darah sebelum dan sesudah dilakukan relaksasi benson pada responden. Hasil tersebut membuktikan hipotesis peneliti yang menyatakan ada pengaruh relaksasi benson terhadapat kadar gula darah pasien DM Tipe II di RST Reksodiwiryo Padang.

\section{DAFTAR PUSTAKA}

Alligood, MR \& Tomey AN. (2012) Nursing Theorist and Their Work, Sixth. Edition, St. Louis Mosby

Barnes, E dan Darryl. (2012). Panduan untuk Mengendalikan Glukosa Darah. Klaten: Insan Sejati 
Benson, H.,\& Proctor, W. (2010). Dasar-dasar Respons Relaksasi. Bandung : Kaifa

Bloom, Benjamin S., etc. (2000). Taxonomy of Educational Objectives : The. Classification of Educational Goals, Handbook I Cognitive Domain. New York Fransisca, Kristiana. (2012).

Awas Pankreas Rusak Penyebab Diabetes. Jakarta: Cerdas Sehat

Hasdianah. (2012). Mengenal Diabetes Mellitus Pada Orang Dewasa dan Anak - Anak Dengan Solusi Herbal. Yogyakarta : Nuha Medika

Journal Medica Volume 5, Issue 1. Benson,. Herbert dan. Stark,. Marg. (2012).Timeless. Healing. (penyembuhansepanjangmasa). Batam: Intraaksara.

Keith, L., Arthur, F., (2016). Clinically Oriented Anatomy, 5th edition. Lippincott Williams \& Wilkins, Philadelphia, USA: Keith, L., Arthur, F., 956-976.

Kurniadi , Helmanu . (2015). Stop Diabetes. Yogyakarta: Istana Media.

Kurniadi dan Nurrahmani. (2014). Stop Diabetes, Hipertesi, Kolestrol Tinggi, Jantung Koroner. Yogyakarta: Istana Media.

Kushariyadi, Setyoadi. (2011). Terapi Modalitas Keperawatan Pada Klien. Psikogeriatrik. Penerbit: Salemba Medika. Jakarta
Lorenz E, Zuehlke H, Kange R, editors. Pathophysiology and Classification of Adhesions. 5 ed. Berlin. Springer-Verlag; (2006)

Nursalam. (2008). Pendidikan Dalam Keperawatan. Jakarta: Salemba Medika

Notoatmodjo, S,.(2015). Metode Penelitian Kesehatan, Jakarta: Rineka Cipta.

Potter, \& Perry, A. G. (2009). Buku Ajar Fundamental Keperawatan: Konsep, Proses, Dan Praktik, edisi 4, Volume.2. Jakarta: EGC.

Smeltzer S dan Bare B. (2002). Buku Ajar Keperawatan Medikal Bedah

Brunner \& Suddarth edisi 8. Volume 2. Jakarta: penerbit Buku Kedokteran Indonesia EGC

Sugiyono, 2009, Metode Penelitian Kuantitatif, Kualitatif dan R\&D, Bandung : Alfabeta

Sujono \& Sukarmin. 2013. Asuhan Keperawatan Pada pasien DM, Yogyakarta-. Graha Ilmu.

Suyono S., (2013)., Patofisiologi Dibetes Melitus:

Penatalaksanaan Diabetes Melitus Terpadu Edisi II. Jakarta: Balai Penerbit FKUI, pp 16-18

World Health Organization (WHO). (2014). Data Diabetes Mellitus. Asia Tenggara: WHO. 